\title{
Discussion of The Government's Leading Function In The Higher Vocational Education School-enterprise Cooperation
}

\author{
Ying Zi \\ Ningbo City College of Vocational technology \\ No.9 XueFu Road, Higher Education Zone, Ningbo city, Zhejiang province, China \\ shadowziying@163.com
} Keywords: Vocational education; School-Enterprise cooperation; Government leading; Innovation
ability

\begin{abstract}
Analysis the existing problems in school-enterprise cooperative education, and explore how to develop the leading function of government in it is the main content of this paper. Through the analysis of school-enterprise cooperative education at home and abroad, and drawing lessons from those successful experiences, meanwhile combing our national situation to set up the Higher Vocational Education School-enterprise Cooperation Model under government leading, to design how to achieving the organizational structure and the execution path for Higher Vocational Education School-enterprise Cooperation under government leading. Only the Higher Vocational Education School-enterprise Cooperation under government leading can play the better advantage for socialism with Chinese characteristics, and promote the deep fusion for School-enterprise Cooperation.
\end{abstract}

\section{Introduction}

School-enterprise cooperative education is an education model that use enterprises as the principle part, and enterprises and schools both involved in teaching activities to enable students practice what they are learning and learn from what they are practicing. Because setting up this model is to train the innovation ability and practice ability for student and adapt the need for applied talents in social, so this model specially conform to the education goals in local higher vocational school ,is the main path for cultivation of talents in local college. Currently although there are some achievements for Higher Vocational Education School-enterprise Cooperation in China, but many problems also exist in main issue, especially how to develop the leading function of government, and didn't cause the attention by different sectors.[1]

\section{Existing Problems In School-enterprise Cooperative Education}

For recent decade or so, there are quite amount of local high education schools and enterprises aggressively seek after and created some effectively school-enterprise cooperative education methods. These efforts appeared to have put some beneficial effects in training application-oriented talents. However, there are still some problems in the implementing practice teaching and following through with it. The school-enterprise cooperative education model which can adapt socialist marketing economy has not been formed yet. To conclude existing problem in local college school-enterprise cooperative education, there are the following sections.

The Weakening Of Government's Leading Position In School-Enterprise Cooperative Education.

The Weakening of Government Legislation in School-enterprise Cooperative Education. Even though our government has set up the guidelines to guide and published regulations to support school-enterprise cooperative education. But the legal system of vocational education is not existed, lack of the special applicable terms and coerciveness.[2] Because of the weakening of government legislation, school-enterprise cooperative education mainly exists as spontaneous and non-government activities. These activities are lack of standardized management and hard to meet 
school-enterprise cooperative education's target.

The Weakening of Enterprises and Social Responsibilities in School-enterprise Cooperative Education. Developed countries stipulate that enterprises are the principle part of school-enterprise cooperative education. Cultivating talents through this education model is a responsibility which has to be agreed to be taken by each enterprise through the explicit legislation. Today the position and social responsibility has been weakened in our school-enterprise cooperative education legislation. Lots of enterprises treat school-enterprise cooperative education as an extra burden. For this, government does not have enough supervision and legal restraint.

The Build Of Out Of School Practice Bases In School-enterprise Cooperative Education Is Difficult

Some of the Practice Bases have been existed in Name Only. Under socialist market economy, state-owned enterprises has been transformed and reorganized to private ones in succession. In such situation, industries only consider economic benefits and they would not be interested in training talents through school-enterprise cooperative education. The practice bases in such enterprises are existing in their name only.

Some of the Practice bases are Only in Name but not in Reality. In school-enterprise cooperation talents cultivation programs, some enterprises start from their own benefits and discard the agreed talents training cooperation plans. They do not pay attention on students' study or practice. For now, lot of enterprises saying that they are providing practical bases for students but in fact, they are not doing the right thing.

Table 1 list the questionnaire by our logistic students in my college who practice out off school in one year. There are 5 kinds of items in it.

The main issues reflect from it are as follow: There is no position changeable during the whole practice process; There is no special person in charge of students spare time after work off. Lack of theory learning by professional teacher. The practice plan can't be implemented. E. Practice time is most from 1-6 months.

From these issue we can see, Some practice bases have lost the function of practice. The principal status of enterprise is weak, and enterprise is lack of the management for practice process. The practice plan and the academic tutoring are hard to be implemented because of the disperse students.

In conclusion, there are serious problems existing in the build of practice bases in school-enterprise cooperative education, especially the formalism issue in school-enterprise cooperation is serious.[3]

Table 1 questionnaire by our logistic students

\begin{tabular}{|c|c|c|c|c|c|c|c|c|c|c|c|c|}
\hline $\begin{array}{l}\text { Item for } \\
\text { survey }\end{array}$ & \multicolumn{3}{|c|}{$\begin{array}{l}\text { If the practice } \\
\text { combine with major }\end{array}$} & \multicolumn{3}{|c|}{$\begin{array}{l}\text { Is there position } \\
\text { changeable } \\
\text { during practice } \\
\text { process? }\end{array}$} & \multicolumn{2}{|c|}{$\begin{array}{l}\text { Is there } \\
\text { practice } \\
\text { plan? }\end{array}$} & \multicolumn{2}{|c|}{$\begin{array}{l}\text { Is there any } \\
\text { professional } \\
\text { teacher in } \\
\text { charge of } \\
\text { theory } \\
\text { learning?. }\end{array}$} & \multicolumn{2}{|c|}{$\begin{array}{lr}\text { Is } & \text { there } \\
\text { special } & \\
\text { person } & \text { in } \\
\text { charge } & \text { of } \\
\text { students } & \\
\text { spare } & \text { time } \\
\text { after } & \text { work } \\
\text { off? } & \end{array}$} \\
\hline $\begin{array}{l}\text { Answer } \\
\text { for } \\
\text { question }\end{array}$ & $\begin{array}{l}\text { Clos } \\
\mathrm{e}\end{array}$ & $\begin{array}{l}\text { commo } \\
\mathrm{n}\end{array}$ & $\begin{array}{l}\text { Not } \\
\text { close }\end{array}$ & Yes & $\mathrm{Nc}$ & Few & Yes & No & Yes & No & Yes & No \\
\hline $\begin{array}{l}\text { The } \\
\text { percentag } \\
\text { e }\end{array}$ & 83 & 17 & & 24 & 59 & 17 & 41 & 59 & 65 & 35 & 6 & 94 \\
\hline
\end{tabular}




\section{The Research Of Higher Vocational Education School-enterprise Cooperation Model Under Government Leading}

Vocational education is occupational, affinity to the people and it is also characteristic in social and public benefits. However, as an economic entity, enterprises tend to follow market-based economic rules, and seek for economic benefits. Therefore, only if government involved in and lead the school-enterprise cooperative education, then the enterprise economy behaviors can be supervised and restrained to ensure the natural function of school-enterprise cooperative education . The functional departments involved such as personnel department, department of labor etc. should also be coordinated and communicated by government.

Some Misconceptions. The implement of government-leading school-enterprise cooperative education accords with our national situations and the development status of current school-enterprise cooperative education. However, there are also some areas have misconceptions for government leading school-enterprise cooperative education.

Some People believe that the Leader Status of Government in School-enterprise Cooperative Education doesn't Conform to the Market Rules. This point of view comes from the Wrong ideological trend of "education industrialization". The main claim of education industrialization is to push education into market, and running education by the economic law, claim to run school as a enterprise and pursue profits to be existed and developed, [4] finally let education become a business activity which is dominated by market rules. The essence of this ideological is the profit-seeking of education and Corporatization of schools.

On the historical course of our socialistic marketing economical system, some people bring the market relationship to inappropriate area in the name of "reformation" or "intensify reformation", blow an over-marketing reform trend. The ex-president of Renmin university of China professor Baocheng Ji write several times to obviously against treating school as a enterprise and advocating education industrialization. [5]

Economics divides social products into private products, public products and quasi-public products. Only private products can be considered as pure commodities and can be marketization. As a social product, education belongs to quasi-public products. At the same time, education has the basic character of public products - public welfare, then education can't abide by marketization.

One-sided Emphasis on Economic Benefit in School-enterprise Cooperative Education. The public welfare character of education ensures that education cannot use profitability as its target. In our country, neither public schools nor private schools can operate for profit purpose. Moreover, they cannot run as an enterprise or industry.

Not only in China, don't run for profit purpose is also a basic education principle all over the world. Today, any nation, any responsible government will treat education development as their basic responsibility and one of the most important public welfare establishments. There is no country in the world push industrialization and marketization education policies to its nationals. And by the most countries in world, even private schools are not private assets but a kind of special public asset which can be assigned to non-profit organizations.

One-sided emphasis on enterprise's economic benefits in school-enterprise cooperative education is an excuse for some enterprises who do not attach importance to such education model. These enterprises claim that government leading school-enterprise cooperative education has increased enterprises' burden and reduced their productivity, this has interfered enterprises' autonomous right. Therefore, these enterprises stand for the free combination of school-enterprise education to avoid their social responsibilities. They are lack of sense of social responsibility.

In fact, this point of view is just a copy of "marketization education" which operates for economic profit purpose. To adjust those wrong opinions, reinforce the government leading position in the school-enterprise cooperative education is necessary. 


\section{Research The Suitable Mode Of School-enterprise Cooperative Education For Chinese Situation}

Government Confirm the Station and Responsibility of Enterprise and School in School -enterprise Cooperative Education by Law. During the development of vocational technology education in world, the developed country always confirm the relationship, station and responsibility of government, enterprise and school in school-enterprise cooperation by law. For instance: U.S.A passed "the law of vocational education" in 1963, passed "amendments for the law of vocational education" in 1968 to hammer at importance of vocational education, and stipulate that enterprise has to invest for vocational education by law responsibility.; In Germany, the general law of education and the law of higher education in every canton always definitely stipulated for higher vocational education to confirm that both side mode is a mode of running school which established by school and enterprise cooperation and be protected by law, and definitely stipulated that the outlay of vocational education by enterprise has to be the 4 times of country's payment[6,7].

In China, State Council made out "the decision of energetically develop vocational education by State Department" on the national vocational education conference in 2005, in this decision, items of the tenth 、 the sixteenth the seventeenth 、 the twentieth are specific for school-enterprise cooperative education, to provide the favored tax policy to encourage enterprise admitting students to practice and pay some work payment. But these policies didn't to be carried out and to be bring into effect because of none intendance and lack of restriction.

Establish the supervise organization for school-enterprise cooperative education under government leading. Government is initiator for school-enterprise cooperation in higher vocational education, therefore government should build the authoritative management institution for higher vocational education and play the role to organize, guide and coordinate.[8]

The country which developed in vocational technology education always established the special organization to harmonize school and enterprise cooperative education, such as the "committee of relationship for university and enterprise in U.S.A" which established by U.S.A; " working line of education-enterprise" and "the higher foundation of education-economy which established by France. U.K established "The training and enterprise Council"(TFC) to encourage enterprise joining vocational education and to harmonize the relationship between school venterprise and student $[9,10]$ " The opinion about further enhance the work for high skill talent" by General Office of the CPC Central Committee and General Office of State Council further clarify that every city can establish training system of school and enterprise cooperation for higher skill talent, the government leader of special office and representative of enterprise and school can constitute the steering committee for training system of school-enterprise cooperation for higher skill talent to research and institute the development plan and training way and target ,to harmonize the cooperation between enterprise and school.

To summarize the successful experience in world, the way of school- enterprise cooperative education under government leading can be concluded as below:

- Government regulate and restrict a the social responsibility, obligation and economy demeanor of enterprise and school in school-enterprise cooperative education by law.

- The government、school and enterprise set up a leading organization together and set up the standing office in government education department. This organization responsible for leading and planning all job in school-enterprise cooperative education, supervising the obligation 、right and profit of school and enterprise in school-enterprise cooperation

- Base on above item, under the unitive plan which established by leading office of schoolenterprise cooperation by national law, school and enterprise can develop different type of education contents to implement and complete the practice teaching task in plan of student training.

Out of School Practice Teaching in School - enterprise Cooperative Education. How toimplement the out of school practice teaching system laid store by enterprise and joined energetically by school under government leading, Guangdong Zhongshan Torch Polytechnic has 
the successful experience on this[11]

Zhongshan Torch Polytechnic implements "3 sides(government、 college and enterprise)" system which makes the leading station of government more important and more effective in all system. In the Zhongshan high tech Zone, government establish the college, the outlay and HR of college are in charge of by Zone committee; Enterprise are introduced by government into industry park and are managed by Zone committee as a company. The leader of high tech Zone Party Committee and Zone Committee takes the position in school, meantime establishes the college directorate and the leaders of some good enterprises take the director position. In other part, they establish "manufacture training campus" by high tech Zone Committee, enterprise and school, and compose a special committee to manage and harmonize the school-enterprise cooperative education by time-meeting in this campus. The good achievement of school and enterprise cooperative education by The Guangdong Zhongshan Torch Polytechnic is the effective result which is caused by government impact with the effective lawmaking, dominant position and strong evaluation and intendance.

To summarize the out of school practice teaching which under government leading, enterprise should be the main part and be actively joined by school, we can see the below contents:

- According to the country lawmaking and unitive plan by school-enterprise cooperation leading organization, enterprise take the main position with government leading and school effective joining to build the out of school practice base with different mode such as "manufacture training campus" and "manufacture training workshop".

- School set up the leading team for student practice teaching to make out the practice teaching plan with enterprise, and totally put the practice teaching plan into effect from different parts such as teacher team, practice outlay and time organizing.

- Enterprise set up the leading team for student practice teaching to build the security system for student practice teaching, and totally put the practice teaching plan into effect from different parts such as enterprise tutor, practice place and equipment, canteen and dormitory.

- Enterprise take the main position with school effective joining to in charge of the teaching 、 manufacture、 living and security issue during student practice.

- Government is in charge of the intendance and evaluation for the process and result of student practice teaching in school-enterprise cooperative education.[11]

\section{Conclusion}

Conclude as above, the detail conceive of Higher Vocational Education School-enterprise Cooperation Model under Government is as figure 1.

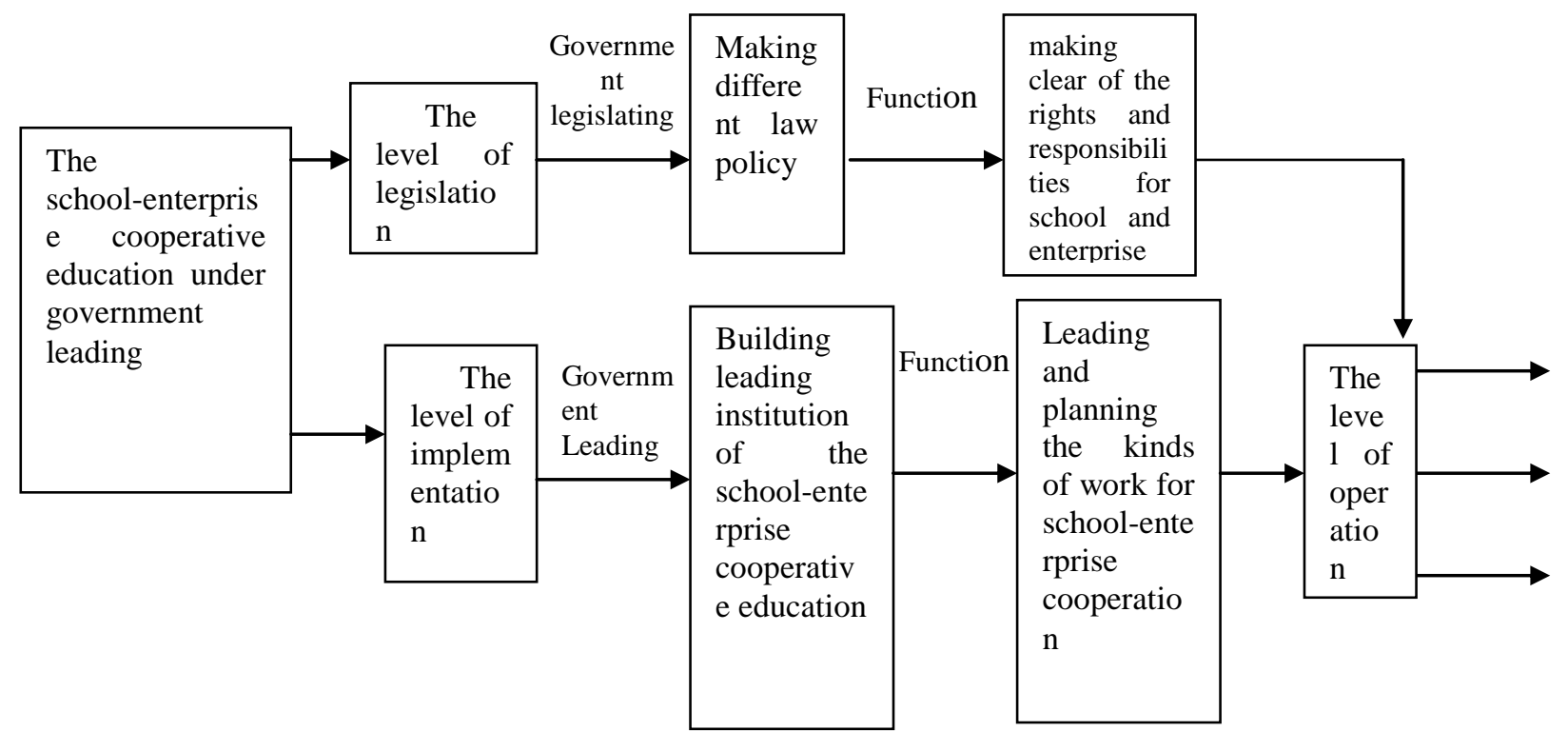

Figure 1. Higher Vocational Education School-enterprise Cooperation Model under Government 
The school-enterprise cooperative education model under government leading can be summarized as: be composed by the lawmaking level, the administer level and other operation level which under administer level. Under government leading the, lawmaking level conform and restrict the social responsibility, obligation and economic behavior of enterprise and school in school-enterprise cooperative education by law. Under government leading, the administer level organize government, school and enterprise together to set up leader organization for school-enterprise cooperative education to lead and contrive all kinds of work. The operation level develop many kinds of school-enterprise cooperation contents under leader organization for school-enterprise cooperative education programming by country law. Government is in charge of supervising how school and enterprise implement their responsibility, obligation and profit in school-enterprise cooperative education.

\section{Reference}

[1] LON Mong-jing, WU Pei, TANG Lin. On the role orientation of the government in the school enterprise cooperation and education in China's Higher Education[J].Higher Education Exploration, 2017,(9): 41-43.

[2] YANG Hon-quan. A study of legislation building during the partnership between school and business of vocational education [D]. WuHan University,2013.09.

[3] JIN Qu-lin. The Situation, Problems and Countermeasures of School-enterprise cooperation in our higher vocational education[D]. Southwest University of Political Science and Law. 2015.03.

[4] SUN Qian-qian. Reflect on the Reform of Education Industrialization in Our Country[J].Journal of Beijing City University.2016,(1):64-67.

[5] CAI Ming-shan ZHU Tong-qin. On the Pitfalls and Perils of"Higher Education Commercialization" [J]. Modern University Education .2016,(6):17-22.

[6] ZHUANG Guo-zhen. Basic experiences and enlightenment on higher vocational education training base construction of developed countries[J].Journal of Henan Institute of Science and Technology, 2004,(6):42-44.

[7] WANG Xiao-yan. Higher Education Reform Modes in University - enterprise

Cooperation Abroad and Its Inspiration for China[J].Heilongjiang Researches on Higher Education.2016,(6):51-53.

[8] ZHANG Jun, LIU Min. A Probe into the Reform of School-Running Mechanism of Higher

Vocational Education Based on School-Enterprise Cooperation [ J $]$. Theory and Practice of Education.2017,37(18):18-20.

[9] LI Bin. Try to talk about the cooperation between colleges and vocational education in our country government dominant strategy[J].Heilongjiang Researches on Higher Education, 2010,(6):90-92.

[10]SU Yu-feng,WANG Man-si, ZHANG Yan-ping. Reform Pattern in Higher Education with School-enterprise Cooperation :Experience from Foreign Countries[J].Special Zone Economy Issue 2017,(5):53-55.

[11]CHEN Xiao-ming. "5 zone" post practice operation mode and explore the enlightenment[J]. Heihe Journal, 2010 , (5):110-112. 